(2) 手術時の膝の軟骨変化と, 将来のレントゲン変 化との関係はなかったかどうか.

解 答整形外科 長谷川 修

(1) $\mathrm{OA}$ A 1 例は, 強い水腫と内反変形を伴ったも
ので, synovectomy と High tibial osteotomy を 併用して，良結果を得た。

(2) RAは手術時, いろいろな段階のものがあり， いわゆる早期のものは予後が良く, レ線的に骨, 軟骨 の変化を来しているものは予後も悪い.

\title{
时関節内外反変形に対する骨切り術とその予後
}

\author{
久留米大学医学部整形外科教室 (主任 : 宮城成圭教授) \\ 国武史重・西川洋三 \\ 井上博
}

\section{Results of Corrective Osteotomy for Varus and Valgus Deformities of the Elbow}

\author{
by \\ F. Kunitake, Y. Nishikawa \& H. Inoue \\ Department of Orthopedic Surgery, Kurme University School \\ of Medicine (Director: Prof. S. Miyagi, M. D.)
}

Thirty-eight corrective osteotomies for varus and valgus deformities of the elbow caused by supracondylar and lateral condyle fracture of the humerus were carried out for the past 19 years. The mean age at the operation was 12 years and 6 months.

Twenty-five cases were examined clinically and roentgenologically on an average of 7 years and 6 months after the operation.

The authors concluded that there was no limited age indication for the osteotomy and the remaining carring angles within 5 degrees in varus and 10 degrees in valgus deformity were negligible for the satisfactory results.

\section{緒}

\section{言}

幼小児上腕骨末端骨折の後遺症としての肘部内，外 反変形は, 美容上醜形を示し高度となれば时関節運動 障害や神経症状を併発するととも稀れではない。

今回われわれは昭和 29 年より 47 年までの 19 年間 に，当整形外科教室においててれら上腕骨末端骨折後 の内外反変形に対して矯正骨切り術を施行した症例の 予後調査をおてなったので報告する.

\section{調 查 対 象}

過去 19 年間に矯正骨切り術をうけた症例は 38 例 (内反时 24 例, 外反时 14 例) であり, 手術時平均年
令は 12 才 6 力月（内反肘 10 才 11 力月, 外反时 15 才 4 力月）で, 受傷より手術までの平均期間は 8 年 5 力 月（内反时 5 年 1 力月, 外反时 9 年 10 力月）であっ た．その発生原因は内反时はすべて上腕骨顆上骨折で あり，外反肘は，上腕骨外顆骨折であり，3例を除き他 はすべて為関節を形成していた。性別は男性に多く， 罹患側は左側に多く認められた。

てれらの症例に対する術式は内反肘では全例上腕骨 顆上部揳状骨切り術のみが施行され, 内固定は Rushpin 22 例, Zuggurtung 法 2 例であった. 外反时では 8 症例 (54\%) 亿尺骨神経麻瘦が認められ，乙れら の症例に対しては 5 例が内上顆切除術, 1 例が神経剝 離術, 2 例が両術式の併用を矯正骨切り術と同時にな 
されている. 内固定は Rush-pin 10 例, Zuggurtung 法 2 例, 内副子 2 例であった。

\section{直接検診症例}

今回直接検診し得た症例は 25 例（内反时 15 例, 外 反时 10 例) であった.

内反肘では手術時平均年令 11 才（最年少 3 才, 最

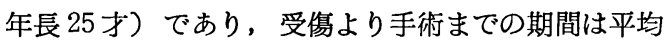
5 年 3 カ月で. 1 年以内に施行されたもの 4 例, 10 年 以上経って施行されたもの 4 例で, 最短 3 力月, 最長 22 年であった，骨切り術より調查時までの 平均期間 は 8 年 9 力月（最短 11 力月, 最長 18 年) であった.

外反时では，手術時年令は 29 才で施行された 1 例 を除き，すべて11才より15才の間におてなわれてお り, 平均 14 才 6 力月であった. 受傷より手術までの 期間は, 最短の 2 力月と最長の 26 年をのぞき, 6 年 より 10 年の間におてなわれており, 平均 8 年 11 力月 であった。手術より調查時までの平均期間は 5 年 11 力月（最短 11 力月，最長 13 年 10 力月）であった.

〈術前変形の程度〉

術前反时度は内反肘では見かけ上，レ線上共に平均 26 度であり，症例の $50 \%$ \% 20 度から 25 度の範囲内 にあった. 外反时の平均は見かけ上 $30^{\circ}$, レ線上 $32^{\circ}$ で あり, 症例の $50 \%$ は見かけ上 $25^{\circ}$ から $30^{\circ}$ ， 乙線上 $30^{\circ}$ から $35^{\circ}$ の範囲内にあった。

〈術前肘関節機能障害と神経症状の程度〉

術前肘関節機能に何らかの障害を認めたものは，内 反肘では 7 例 $(45 \%)$, 外反时では 6 例 $(60 \%)$ であ り, 内反肘では伸展, 屈曲共に障害されたものは 3 例 で, 伸展および屈曲のみ障害されたものはそれぞれ 1 例および 2 例であり, そのうち $20^{\circ}$ 以上伸展制限のあ るものは 2 例で, $90^{\circ}$ 以上の高度な屈曲制限を認める ものは 1 例であった．また回内，回外のあきらかに障 害されたものは 1 例認められた. 外反时では伸展, 屈 曲共に障害されていたもの1例で, 伸展のみ障害され ていたものは 4 例, 屈曲のみ障害されていたもの 1 例 であり, そのうち $20^{\circ}$ 以上の伸展制限の認められたも のは 2 例であるが, 屈曲障害は何れも軽度であった. 回内, 回外運動の制限されたものは認めなかった.

術前内反时には神経麻㾯を合併した症例はなかった が, 外反时では尺骨神経不全麻㿇を伴ったもの3 例, 遅発性尺骨神経麻瘦 4 例と，10 例中 $70 \%$ 亿神経症状 が認められた。また遅発性尺骨神経麻瘦を合併したも
のでは, 受傷後 17 年して 発生しているもの 1 例で, 他の 3 例は 6 年から 7 年の間に起てっている.

\section{〈手術々式〉}

内反时 15 例では 全例上腕骨顆上部骨切り術のみが 施行され，内固定は Rush-pin 13 例，Zuggurtung 法 2 例であった.

外反肘 10 例では 全例内側経路による顆上部矯正骨 切り術が施行され, 内固定は Rush-pin 7 例, 内副子 1例, Zuggurtung 法 2 例で, 尺骨神経麻瘦わよび不 全麻痺を合併する 7 例に対しては, 内上顆切除術が 4 例に, 神経剝離術が 1 例, 両者の併用が 2 例に骨切り 術と同時に施行されている.

\section{調 查 成 續}

\section{i ) 反肘度の推移}

見かけ上の反肘度は，内反肘では術前平均 $26^{\circ}$ であ ったものが調查時は $10^{\circ}$ と改善されており, 調查時 $10^{\circ}$ 以内の内反位に矯正されたものが 10 例で約 $67 \%$ に認められる. 外反肘では術前平均 $30^{\circ}$ であったもの が調查時 $7^{\circ}$ と改善され， $10^{\circ}$ 以内の外反位に矯正さ れたものが8例で $80 \%$ \%った。

直接検診し得た 25 例のうち, 術前, 術後, 調查時 の反肘度の推移をレ線学的に計測し得た症例は 18 例

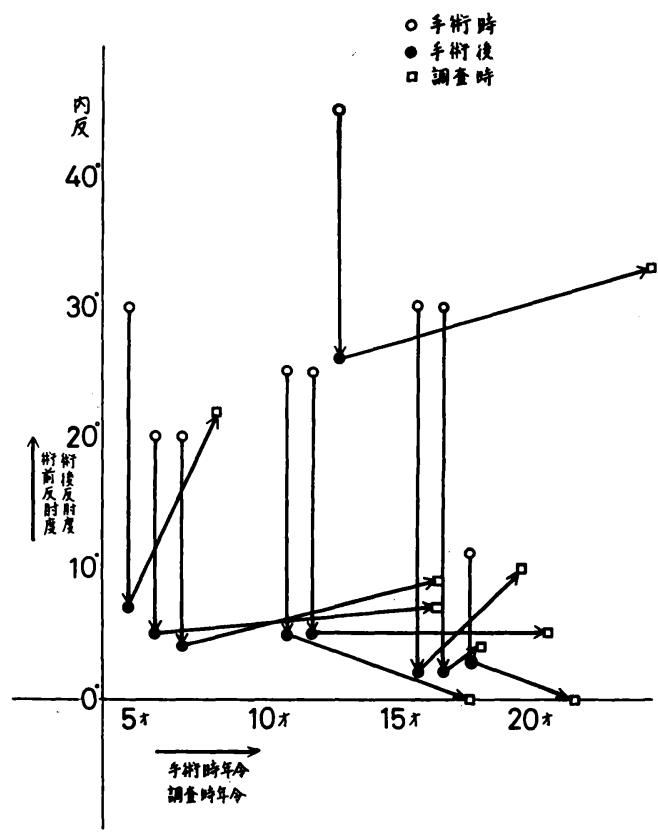

表 1 内反时推移 
(内反肘 9 例, 外反肘 9 例) であった.

内反时 9 例のうち手術後 $5^{\circ}$ 以内の内反位に矯正さ れたもの 7 例であり，とのうち調查時の戻りが $5^{\circ}$ 以 内に納まっているもの3 例, 戻りが全く認められない もの 1 例, 矯正の増強がみられたもの 2 例であり, 他 の 1 例は $8^{\circ}$ の戻りが認められた。また手術後矯正が $5^{\circ}$ 以内の内反位に矯正できなかった 2 例のうち 1 例は術 前反时度が $45^{\circ}$ と強く術後矯正が内反位 $26^{\circ}$ しかな く, 調査時 $6^{\circ}$ の戻りが認められ, 残りの 1 例は術後 内反位 $7^{\circ}$ に矯正されているものの調査時内反 $22^{\circ}$ と, $15^{\circ}$ の戻りがみられた。 またレ線上調查時の内反平均 は $10^{\circ}$ であり術前より $16^{\circ}$ の改善を認めた（表 1 ）.

外反肘では 9 例中 8 例が $10^{\circ}$ 以内の外反位に知正さ れ，そのうち調查時 $5^{\circ}$ 以内の戻りを示したもの 4 例 で，全く戻りのないもの 2 例であった。他の 2 例も 6゚〜10の範囲に戻りが認められたが，うち 1 例は偽 関節を形成し再手術をうけた症例である．矯正が $13^{\circ}$ 外反位までと不充分であった 1 例には $4^{\circ}$ の戻りが認 められた。なおレ線上の調查時平均外反度は $7^{\circ}$ であ り, 術前平均より $25^{\circ}$ の改善が認められた（表 2 ）.

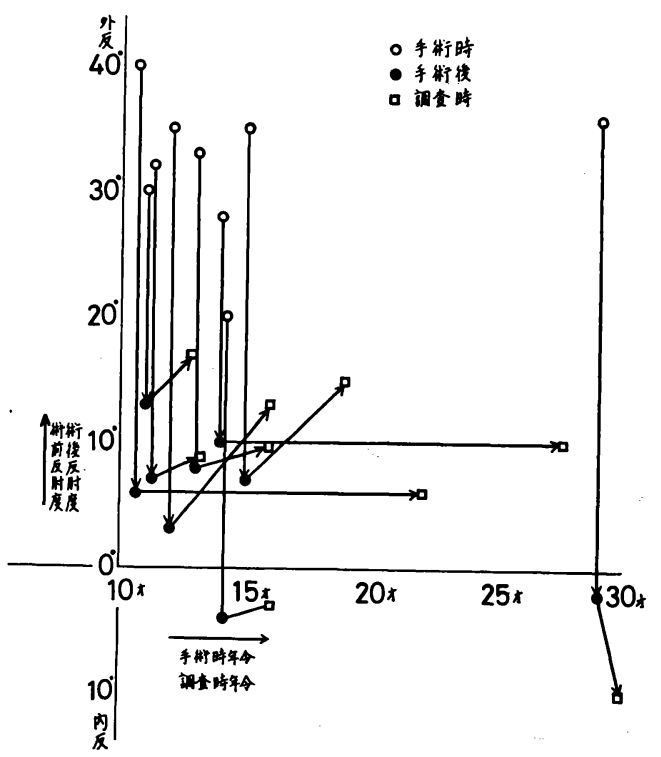

表 2 外反时推移

ii ）时関節機能および神経症状

内反时では調查時何らかの機能障害を有した症例は 5 例 (33 \&) で術前の 7 例 $(45 \%)$ と比較して多少 の改善がみられ，術前より制限の増覀したものは伸展
運動に 2 例, 屈曲運動に 1 例みられたが, 何れも $15^{\circ}$ 以上の制限増悪はなかった。回内, 回外運動は全症例 正常範囲内であった。

外反时では術前 6 例 (60\%) 亿何らかの 機能障害 を認めたが，調查時 4 例（40\%）と減少しており， 術前より増覀した 症例は, 时関節の可動域が術前の $140^{\circ}$ から $85^{\circ}$ に減少した偽関節形成例を除き認めら れず, 改善されたものの中では特に伸展運動に著明 で, $10^{\circ}$ から $20^{\circ}$ の改善を認めたもの 3 例, $20^{\circ}$ 以上 の改善を認めたもの 2 例であった.

内反时では術前神経症状を伴ったものはみられない が, 術後橈骨神経麻㽻をきたし神経剝雄術で治痽した 1 例がある。

外反时では尺骨神経不全麻痺を合併していた 3 例の うち, 症状の消失したものは 2 例で, 他の 1 例は調査 時も時々シビレ感を訴えていた. 遅発性尺骨神経麻瘏 を伴っていた 4 例のうち 2 例は軽度の筋萎縮を残すも 自覚症状はすべて消失しているが，他の 2 例はシビレ 感が残存し, 術前の症状と全く変らなかったものもあ る. また骨切り術後 5 年目に遅発性尺骨神経麻㾝をき たした症例が 1 例あり, 内上顆切除術と神経剝離術を うけている. この症例は外反 $30^{\circ}$ であったものがレ線 推移で術後 $6^{\circ}$, 調查時 $6^{\circ}$ と良好な成績を納めていた が, 術後より内顆の突出が著明で尺骨神経溝も浅かっ た（表3）。

iii) 満 足 度

表 3 外反时に打ける尺骨神释麻瘏

\begin{tabular}{|c|c|c|c|c|}
\hline $\begin{array}{l}\text { 年 } \\
\text { 令 }\end{array}$ & \begin{tabular}{|}
$\mid \begin{array}{l}\text { 受傷より } \\
\text { 手術まで } \\
\text { の期間 }\end{array}$ \\
\end{tabular} & 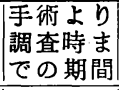 & $\begin{array}{l}\text { 骨切術に併 } \\
\text { 用せる手術 }\end{array}$ & 後 \\
\hline 14 & $\begin{array}{l}9 \text { 年 } \\
2 \text { 力月 }\end{array}$ & $\begin{array}{l}1 \text { 年 } \\
9 \text { 力月 }\end{array}$ & 内上顆切除術 & $\begin{array}{l}\text { シビレ感残存 } \\
\text { (時々) }\end{array}$ \\
\hline 11 & 6 年 & $\begin{array}{l}3 \text { 年 } \\
1 \text { 力月 }\end{array}$ & " & 治 \\
\hline 13 & 10 年 & $\begin{array}{l}3 \text { 年 } \\
1 \text { 力月 }\end{array}$ & " & "I \\
\hline 12 & 7 年 & $\begin{array}{l}4 \text { 年 } \\
11 \text { 力月 }\end{array}$ & 神 経 剝 離 術 & " \\
\hline 15 & 10 年 & $\begin{array}{l}4 \text { 年 } \\
2 \text { 力月 }\end{array}$ & $\begin{array}{l}\text { 神経剝離術十 } \\
\text { 内上顆切除術 }\end{array}$ & " \\
\hline 29 & 26 年 & 11 力月 & " & 不 \\
\hline 11 & 6 年 & $\begin{array}{l}2 \text { 年 } \\
5 \text { 力月 }\end{array}$ & 内上顆切除術 & $\begin{array}{l}\text { 筋萎縮軽度, } \\
\text { 筋力が弱い }\end{array}$ \\
\hline
\end{tabular}


美容上および機能上の患者自身の満足度を検討して みると, 内反时では 15 例中 12 例が手術に対して満足 しており，不満の 3 例は矯正か始めから不充分である か, 反肘度に戻りが認められたものである. 外反时で は偽関節を形成した症例をのぞき美容上はすべて満足 している.

また調査時反时度が $10^{\circ}$ 以内に納まっているものは 美容上の満足度は充分得られている。

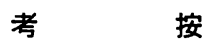

幼小児上腕骨末端骨折は後遗症として肘関節内外反 変形, 时関節機能障害, 神経麻痖がしばしばおてるも のであり, 中でも内反変形の発生頻度は諸家の報告で も高く，教室の寺本も $44.1 \%$ 頻度で発生するてと を発表している．発生原因は今回の調査対象症例では 内反时は全て上腕骨顆上骨折，外反肘は全て上腕骨外 顆骨折である.

内反肘の発生機序は, 末梢骨折片の橈側凸届曲転位 により一次的に発生するという説, 発育異常によって 二次的に発生増強するという説，および混合説とがあ るが, 宮城, 寺本は治療終了時における骨折片の橈側 凸屈曲転位によって一次的に発生し, 趣転々位はその 発生を助長するてとを発表したが，今回のわれわれの 調查において, 矯正骨切り術後の反时度の推移と, 手 術時年令や, 受傷より手術までの期間との間に何ら関 係が認められないととより肯定できる.

骨切り術の時期については幼小児期のものと, 少年 期との間にレ線推移上に特徴的な差異が認められない ので，自家矯正限界内といえども早期の矯正骨切り術 を施行してもよいものと思われる．

骨切り術における矯正角はレ線推移を参考にすれ ば, 内反时では 50 以内の内反位に矯正されたもので は, 術後の戻りが $10^{\circ}$ 以内の内反にとどまる症例の割 合が $86 \%$ であり, 調査時 $10^{\circ}$ 以内の内反肘患者がす べて満足しているととからるし健側と同程度まで矯 正できない場合は，内反 $5^{\circ}$ 以内に䌊正すれば予後も よいと考えられる。

外反肘ではレ線推移で $5 \circ$ 以内の戻りを示したもの が $76 \%$ あり，偽関節を形成した 1 例をのぞき，手 術に満足しているととと, 时関節の生理的外反を考え 合わせると，健側と同じ 反时度に矯正できない場合 は，外反 $10^{\circ}$ 以内に矯正すればよいと思われる。
また骨切り術後时関節機能制限の増悪した症例は， わずかであり，その程度も弱いが，更に良い結果を得 るために，われわれは最近 Zuggurtung 法を使用し， 早期に後療法を開始している. 外反时に神経症状を伴 った症例については，できるだけ早く骨切り術と併用 して神経症状に対する処置を施行した方が予後も良 く，早期に適切なる手術療法が望まれる。

結語

上腕骨末端骨折後の内外反时に対して矯正骨切り術 を施行された 38 例につき予後調查をおてない，直接 検診し得た 25 例につき結果を報告した.

1 ) 内反変形の推移と手術時年令, および受傷より 骨切り術までの期間に何らの関係も認められず, 一次 発生説が肯定できる.

2 ）骨切り術の手術時期は自家矯正限界内といえど も早期に施行してよい.

3 ）反时の矯正が健側と同じ程度までおてなわれる のが理想的であるととは論をまたないが，私達の症例 をみると内反肘は内反 $5 \circ$ 以内に, 外反肘は外反 $10^{\circ}$ 以 内に矯正された例では全例, 機能的, 美容的見地より 患者は充分満足していた。

追 加新日鉄八幡製鉄所病院 平宏 章 肘関節の内反外反変形を矯正するためにZZ状骨切り 術を試みた。

従来の楔状骨切り術で生ずる遠位骨片と近位骨片間 の階段状変形を改善し，また骨接触面積も広いので骨 瘷合も早期に期待できる.

更にわれわれはての方法を膝関節にも応用している が, 固定も簡単で腓骨の処理も必要がなく, 矯正角度 が大きい時でも従来の楔状骨折り術で問題になる滕蓋 靱帯の弛緩の心配もなくよい方法だと思われる。

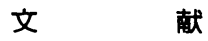

1）石九，ほか：整形外科と災害外科. 12, 19, 1962.

2）伊勢：整形外科. 14, 921, 1963.

3）児玉，ほ加：整形外科. 13，905，1962.

4）神，ほ加：東北整災紀要. 13，245，1970.

5）小串, ほ加：整形外科と災害外科. 18, 107, 1968.

6）前山，ほか：整形外科と災害外科. 8, 164, 1959.

7）寺本：久留米医会誌. 33，984， 1970. 